\title{
Purification, Characterization and Application of Polygalacturonase from Aspergillus niger CSTRF
}

\author{
Arotupin Daniel Juwon*, Akinyosoye F. A. and Onifade Anthony Kayode \\ Department of Microbiology, Federal University of Technology, PMB 704, Akure, Nigeria \\ E.mail: daniel juwon@yahoo.com
}

Received 13 September 2012; Received in revised form 16 April 2012; Accepted 18 April 2012

\begin{abstract}
Aims: The research was carried out to study the purification, characterization and application of polygalacturonase from Aspergillus niger CSTRF.

Methodology and Results: The polygalacturonase (PG) from the fungus was purified by ammonium sulphate precipitation and dialysed. The resulting fraction of the enzyme was further separated by molecular exclusion and ion exchange chromatography. The enzyme was purified 28.19 fold with a yield of approximately $69 \%$ following purification with SP C-50. It has a relative molecular weight of 79,430 daltons and markedly influenced by temperature, $\mathrm{pH}$ and substrate concentrations of reactions with optimum activity at $35^{\circ} \mathrm{C}, \mathrm{pH} 4.0$ and $8 \mathrm{mg} / \mathrm{mL}$ respectively. The $P G$ was heat stable over a broad range of temperatures. Line weaver-Burk plot for the apparent hydrolysis of pectin showed approximately $\mathrm{Km}$ value of $2.7 \mathrm{mg} / \mathrm{mL}$. The activity of the enzyme was enhanced by $\mathrm{Na}^{+}, \mathrm{Ca}^{2+}, \mathrm{Mg}^{2+}$ and $\mathrm{Zn}^{2+}$, while EDTA, $\mathrm{PbCl}_{2}, \mathrm{HgCl}_{2}$ and IAA were inhibitory. The ability of the purified enzyme to clarify fruit juice was also investigated. Conclusion, significance and impact of the study: This study revealed that polygalacturonase possesses properties for clarification of fruit juice and by extension bioprocessing applications.
\end{abstract}

Keywords: Polygalacturonase, molecular exclusion, dialysed, bioprocessing, purification

\section{INTRODUCTION}

Polygalacturonases otherwise referred to as pectic hydrolyases are pectic enzymes that hydrolyse pectic substances into their monomeric units. They are known to be responsible for the hydrolytic cleavage of the B-1, 4glycosidic of the galacturonan, moiety of pectic substances (Rose, 1980; Forgarty and Kelly, 1983). However, extracellular polygalacturonases catalyses the hydrolytic cleavage of terminal X-1, 4-glycosidic bonds (pectic acid) releasing galacturonic acid as the main product (Kluskeus et al., 2005).

Polygalactuonases appeared to be the most frequently encountered pectic enzymes. They are formed in the majority of plant tissues particularly in ripening fruits. Also many plant pathogenic and saprophytic microorganisms produced polygalacturonases (Parvateesam and Verma, 1992; Ajayi et al., 2003).Most fungi that exhibited pectolytic activity produce polygalacturonases either as sole pectic enzymes as observed in Sacchromyces fragilis (Phaff, 1966), or in association with either or both pectinmethylesterases and pectinlyase (Odutola and Ikenebomeh, 1997). The critical role of these enzymes in the degradation of the host middle lamella and cell walls, leading to plant tissues merceration and cellular death had been documented (Peter et al., 1990; Ajayi et al., 2003; Chuku et al., 2005). The infection of cotton seedlings by Rhizoctonia solani, soft rot yam and sweet potato, brown rot of apple by Monilinia species and deterioration of tomato by Botryoplodia theobromae Pat have been reported to produce polygalacturonases and other cell wall degrading enzymes (Bateman and Miller, 1966; Olutiola et al., 1982; Weeransinghe and Naqui, 1985; Shamar and Kaul, 1985; Odutola and Ikenebomeh, 1997; Ajayi et al., 2003). The culture filterates of Collectotrichum lagnarum exhibited polgalactuonase activity (Mills and Wood, 1985).

In addition, the culture filterates of Collectotrichum lindermathianum in vitro (two constitutive), Phytophthora infestans, Fusarium solani, F. oxysporium and Cochlobus carbonum were reported to contained polygalacturonases (Barth et al., 1981; Jarvis et al., 1982; Perez-Artes and Tena, 1989; Walton and Cerone, 1990). Other fungi reported to have produced polygalacturonases in-vitro included F. moniliforme (Caprari et al., 1993; Niture and Pant, 2004; Fontana et al., 2005), Coryphonetia parasitica (Gaoand Shain 1994), Collectotrichum lindermathianum (Hugouuvienx et al., 1995), Aspergillus species (Solis et al., 1996; Fontana et al., 2005; Debing et al., 2006) and Phoma sorghina (Akiyosoye and Oboh, 2004).

Pectolytic enzymes of fungal origin (Alves et al., 2002; Akinola and Onaolapo, 2003) have long been used for the extraction, clarification and depectinization of juices (Alkorta et al., 1998; Silva et al., 2002). Most potential sources of polygalacturonases are usually from 
pathogenic fungi of plants and fruits. Therefore, sourcing for polygalacturonases from non-pathogenic microorganisms could ease off the pathogenic action of the polygalacturonase from its prime origin. Also, the adoption of the beneficial aspect of polygalacturonases in Nigerian industries is relatively very low. In view of these scenario, this work focused on the purification, characterization and application of polygalacturonase from Aspergillus niger CSTRF.

\section{MATERIALS AND METHODS}

\section{Sources of organisms}

The Aspergillus niger CSTRF used in this study was isolated from cultivated soils of Teaching and Research Farm of the Federal University of Technology, Akure, Nigeria. The organism was routinely grown and maintained according to Arotupin et al. (2008). The prelimnary screening of the organism for elaboration of polygalcturonase (PG) was carried out with the method of Kimural et al. (1993).

\section{Preparation of medium and inoculation of fungus for} the production of PG

The medium consisted of $50 \mathrm{~mL}$ basal medium (Olutiola and Akintunde, 1979), in $250 \mathrm{~mL}$ conical flasks. Zeropoint-five milliter spores of $48 \mathrm{~h}$ old culture of the fungus (Akinyosoye and Akinyanju, 1989), was used to inoculate the basal medium.

\section{Polygalacturonase assay}

Polygalacturonase activity of the culture filterates resulting from the fungal growth was assayed by the method of Miller (1959). The reaction mixture consisted of $1 \mathrm{~mL}$ of $1.2 \% \mathrm{w} / \mathrm{v}$ pectin in $1 \mathrm{~mL}$ of $0.1 \mathrm{M}$ citrate -phosphate buffer of $\mathrm{pH} 5.0$ and $1 \mathrm{~mL}$ of culture filterate (crude enzyme solution). Control experimental tubes contained the same amount of substrate and $1 \mathrm{~mL}$ of culture filterates and the mixture was boiled for 20 minutes. Both the experimental and control tubes were subsequently incubated at $35^{\circ} \mathrm{C}$ for $3 \mathrm{~h}$. The amount of reducing sugars released into the reaction mixture was determined by using 3, 5-dinitrosalicylic acid (DNSA) reagent. One unit of PG activity was defined as the amount of enzyme in $1 \mathrm{~mL}$ that would liberate reducing sugars equivalent to $1 \mathrm{mg}$ galacturonic acid per minute under the specific conditions of reaction.

\section{Precipitation and dialysis of enzyme}

The crude enzyme was subjected to ammonium sulphate precipitation (Olutiola and Akintunde, (1979) and dialysed using acetylated cellophane tubing from Visking tubing (Gallenkamp) (Whitaker et al., 1963). The protein content was determined according to the method of Lowry et al. (1951).

\section{Caliberation of Sepadex G-100 chromatography}

A vertical glass tube chromatography column $1.5 \times 70 \mathrm{~cm}$ (Pharmacia Sweeden) was used. Sephadex G-100 was employed for the fractionation of the enzyme. The packedcolumn was eluted and caliberated with proteins of known molecular weights (Arotupin et al., 2008).

\section{Application of the enzyme to sephadex G-100 column}

The dialysate enzyme concentration $(10 \mathrm{~mL})$ was applied to the eluted column as described by Olutiola and Ayres (1973). Five milliters fractions were collected and protein content determined at $280 \mathrm{~nm}$. Fractions with proteins were subsequently assayed for $P G$ and protein as earlier described.

\section{Fractionation of enzyme by ion-exchange chromatography}

The Sephadex C-50 column was prepared like Sephadex $\mathrm{g}-100$ column and packed in a shorter column $(2.5 \times 40 \mathrm{~cm}$ Pharmacia Sweeden). Ten-milliters of the pooled enzyme concentrate was applied to the eluted column. Fivemilliters fractions was collected and assayed for PG and protein content.

\section{Effect of physicochemical factors on purified enzyme}

The effects of temperature, heat (temperature) stability, $\mathrm{pH}$, substrate concentration and chemical agents on enzyme activity were determined by the method of Arotupin et al. (2008).

\section{Clarification of pineapple juice}

The preparation was carried out with a slight modification of the method of Akinola and Onaolapo (2003). The method involved pulping of $20 \mathrm{~kg}$ pineapple fruit in a pulper $(240 \mathrm{~mm} \times 820 \mathrm{~mm})$. The pulp was hydrolysed in $500 \mathrm{~g}$ per batch of pulp using enzyme concentrations of 0 $\%, 20 \%, 40 \%, .60 \%, .80 \%, 1.0 \% \mathrm{v} / \mathrm{w}$ at $25{ }^{\circ} \mathrm{C}$ for 10 min, $30 \mathrm{~min}, 60 \mathrm{~min}, 90 \mathrm{~min}$ and $120 \mathrm{~min}$. The total solid content (Brix) of resulting juice was determined with hand refractometer, $\%$ acidity was determined as anhydrous citric acid and yield of free flow juice was determined on percentage basis (AOAC, 1984).

\section{RESULTS AND DISCUSSION}

The fungus Aspergillus niger CSTRF, when grown on mineral medium containing pectin (Sigma) produced polygalacturonase. The production of the $P G$ into the culture filterates of the fungus confirmed the hydrolysis of pectin leading to the production of PG. Arotupin et al. (2008) had earlier reported the hydrolysis of pectin in the culture medium of $A$. repens. Similarly, the hydrolysis of pectin as the main carbon source in culture media by $A$. flavus and $A$. niger had been documented (Fredrick et al., 1990; Casida, 1997). Also, the ability of $A$. flavus to grow 


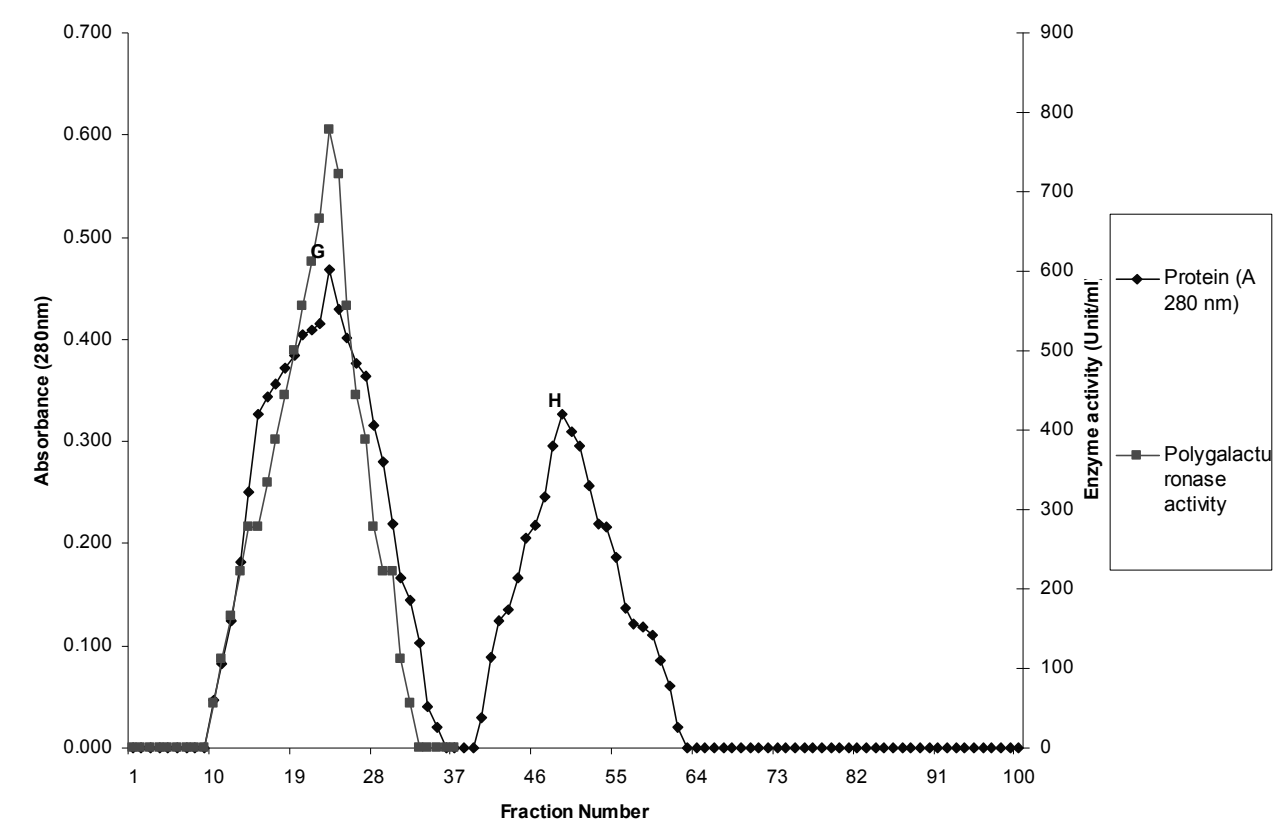

Figure 1: Gel (G-100) separations of proteins in concentrated extract of $A$. niger and enzymatic activity of the fractions

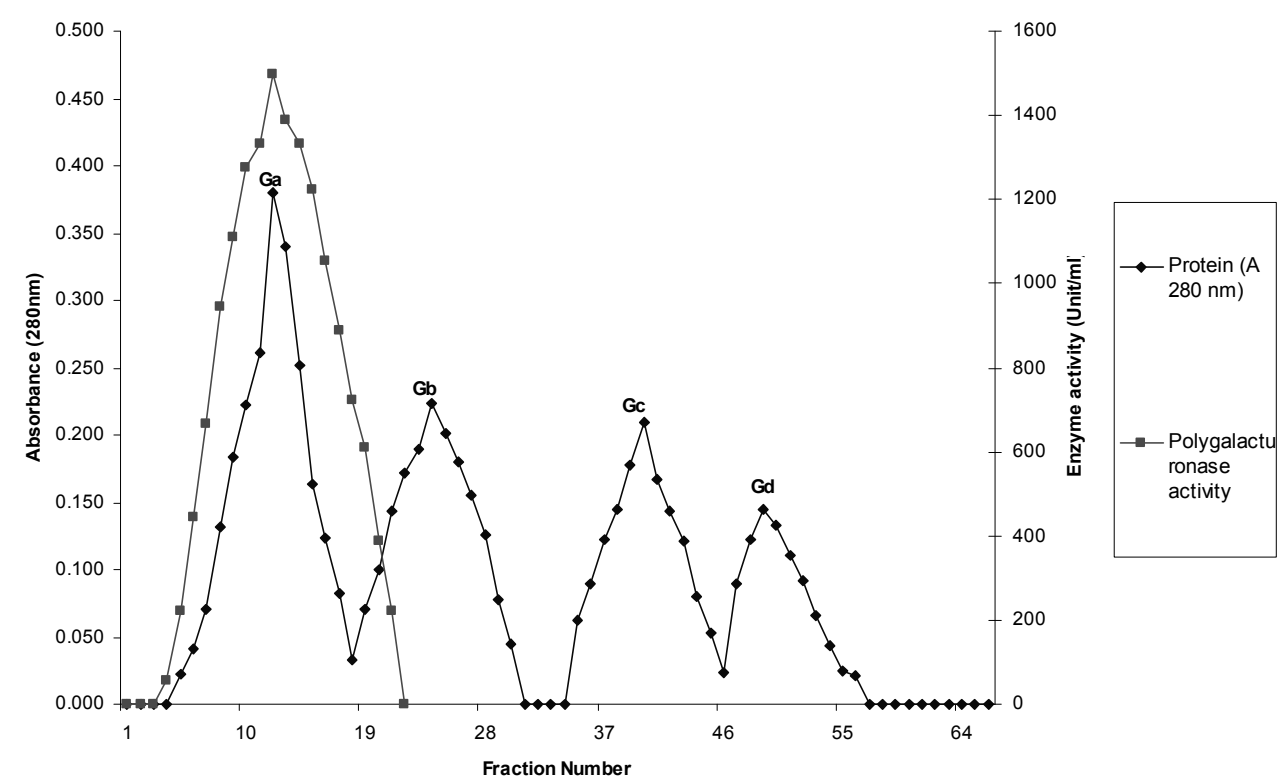

Figure 2: Separation by ion exchange chromatography (Sp Sephadex C-50) of proteins extracted from $A$. niger separated by gel filtration and enzyme activity of the fractions

on carbon substrates including pectin had been reported as an indication of its utilization by the fungus (Arotupin, 2007). The production of PG by Aspergillus, Fuasrium, Penicillium, Thermoascus, Lentinus species on various substrates during solid substrate fermentation and submerged fermentation (Favela-Torres et al., 2006) are strong evidences of the hydrolysis of pectin and pectin containing materials for the growth of the fungi.

\section{Purification of polygalacturonase from Aspergillus niger CSTRF}

Figure 1 showed two absorption peaks designated as $G$ and $H$ respectively by the ammonium-dialysate fractions on Sephadex G-100 column. The G component which was the major peak of $A$. niger presented $P G$ activity, while peak $H$ had no $P G$ activity. Furtherance to the 
Table 1: Purification of polygalacturonase (PG) from Aspergillus niger

\begin{tabular}{llccccc}
\hline Enzyme & Fraction & Total activity $(\mathrm{U})$ & Total protein $(\mathrm{mg})$ & Specific activity $(\mathrm{U} / \mathrm{mg})$ & Purification & Yield \\
\hline PG & Crude & 10800 & 3670 & 2.94 & 1 & 100 \\
& $\left(\mathrm{NH}_{4}\right)_{2} \mathrm{SO}_{4}$ & 9200 & 966 & 9.52 & 3.24 & 85.19 \\
& $\mathrm{G}-100$ & 7777.8 & 140 & 55.56 & 18.90 & 72.02 \\
& $\mathrm{SP} \mathrm{C}-50$ & 7500 & 90.5 & 82.87 & 28.19 & 69.44 \\
\hline
\end{tabular}

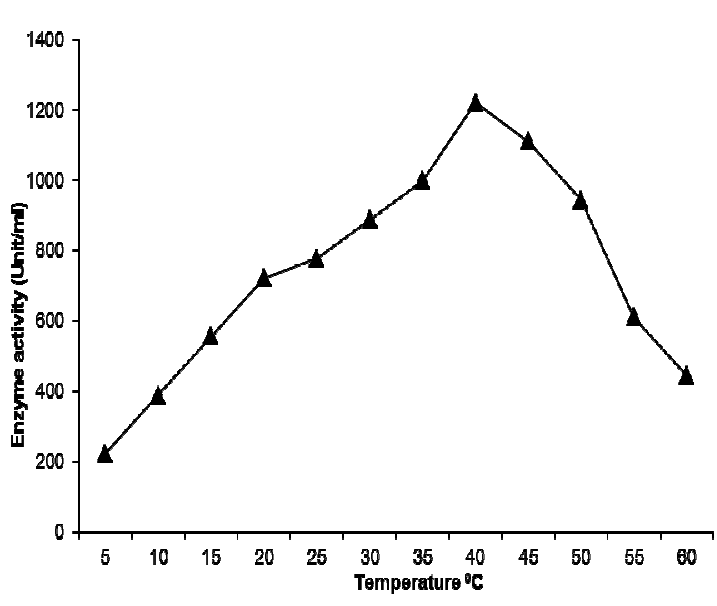

Figure 3: Effects of temperature on the purified (sp C50 fraction) polygalacuronase activity $A$. Niger

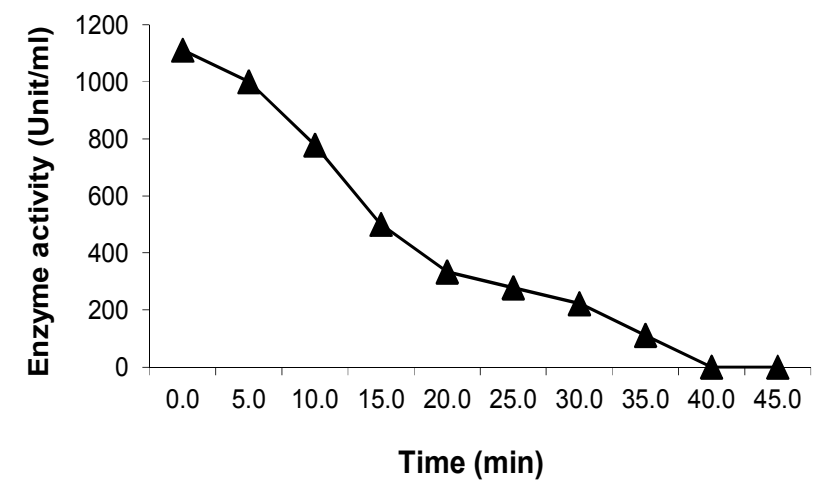

Figure 4: Effect of duration of heating (60 C) on purified (sp C-50 fraction) polygalacturonase activity of $A$. niger.

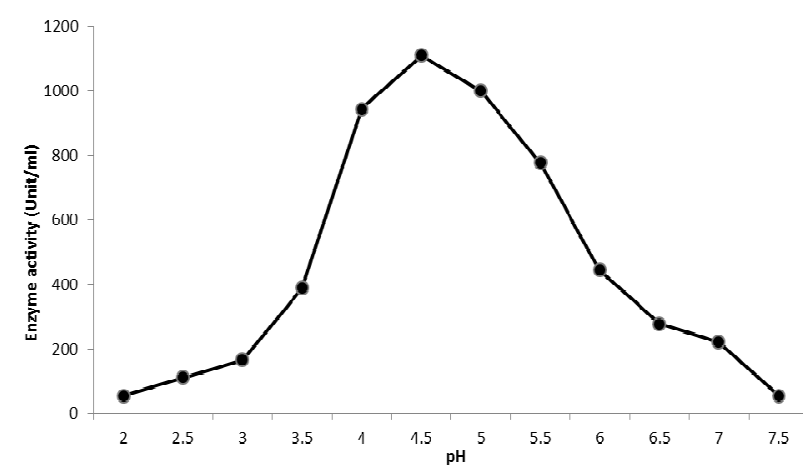

Figure 5: Effect of $\mathrm{pH}$ on the purified (sp C-50 fraction) polygalacturonase activity of $A$. niger fractionation of the components of peak $\mathrm{G}$ of $A$. niger on $\mathrm{Sp}$ sephadex C-50, four peaks of absorption were displayed as $\mathrm{Ga}, \mathrm{Gb}, \mathrm{Gc}$ and $\mathrm{Gd}$ respectively. However, only component $\mathrm{Ga}$ exhibited PG activity, while other peaks lack enzyme activity (Figure 2). Table 1 showed approximately 28 purification fold and $69 \%$ yield of the enzyme fractions on ion exchange chromatography. The fractionation of the ammonium sulphate-dialysate fractions on Sephadex G-100 tend to point to the pattern of synthesis of PG. The position of the enzyme on the chromatography suggested that only PG1 was produced during growth.

However, Silva et al. (2002) suggested several peaks of PG activity to be PGI, PGII and PGIII in order of production. In this study, the production pattern of PG could be described as non sequential. Sequential production of pectinases-PG had been reported by various authors for different microorganisms (Crotti et al., 1999; Soares et al., 1999; Silva et al., 2002). The PG molecular weight from $A$. niger was approximately 79,430 daltons. Jayani et al. (2005) reported low molecular weights PGases ranging from 35 to 496 daltons for different species of fungi. Of all the reasons adduced by Oyede (1998) for the differences in molecular weights, nature and type of organisms used, substrates employed and analytical methods in addition to the monomeric units of the polypeptides could justify the differences.

\section{Characteristics of purified enzyme (Temperature optimum)}

The highest $P G$ activity was observed at $40{ }^{\circ} \mathrm{C}$ (Figure 2). Also, $A$. niger PG lost approximately $10 \%$ of activity when heated for $5 \mathrm{~min}$. However, the enzyme retained approximately $10 \%$ of activity on heated for 35 minutes (Figure 3). The results indicated that maximum quantity of PG activity was considerably influenced by temperature. The optimum temperature for PG activity of $A$. niger was $40{ }^{\circ} \mathrm{C}$ after which there was a decline in the enzyme activity. This clearly showed that higher temperatures affected the activity of the enzyme. Similar observation had been reported by Palaniyappan et al.(2009). Also, PG produced by $A$. flavus, $A$. fumigatus and $A$. repens exhibited maximum activity at $35^{\circ} \mathrm{C}, 40^{\circ} \mathrm{C}$ and $45^{\circ} \mathrm{C}$ respectively (Arotupin, 2007). Olutiola (1982) observed temperature of $35^{\circ} \mathrm{C}$ as optimum for $\mathrm{PG}$ from Penicillium citrinum. Barthe et al. (1981) and Yoon et al. (1994) documented temperature of $40{ }^{\circ} \mathrm{C}$ for the maximum $P G$ activity from Collectotrichum inidermathianum and Gernoderma incidum. This same temperature optimum was implicated for the PG obtained from $A$. niger, Botryodiplodia theobromae and Penicillium variabile 


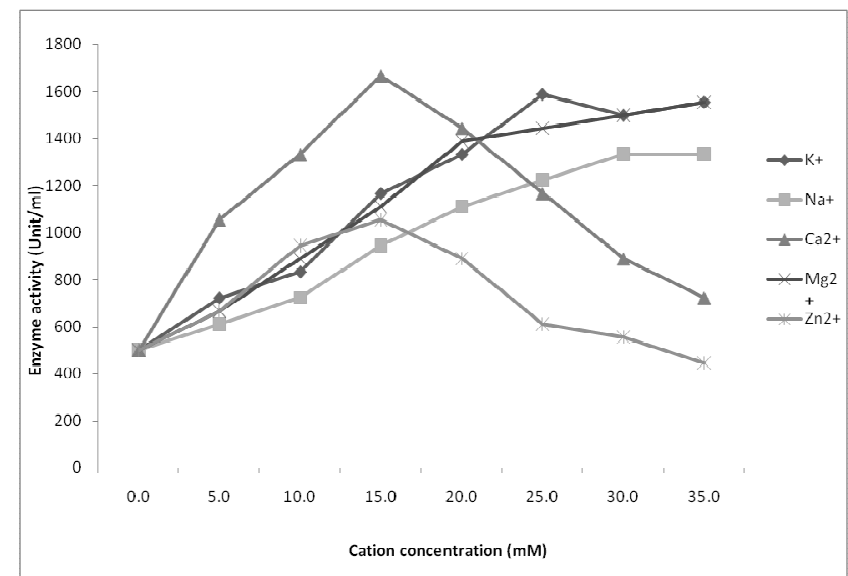

Figure 6: Effect of cations on purified (sp C-50 fraction) polygalacturonase activity of $A$. niger

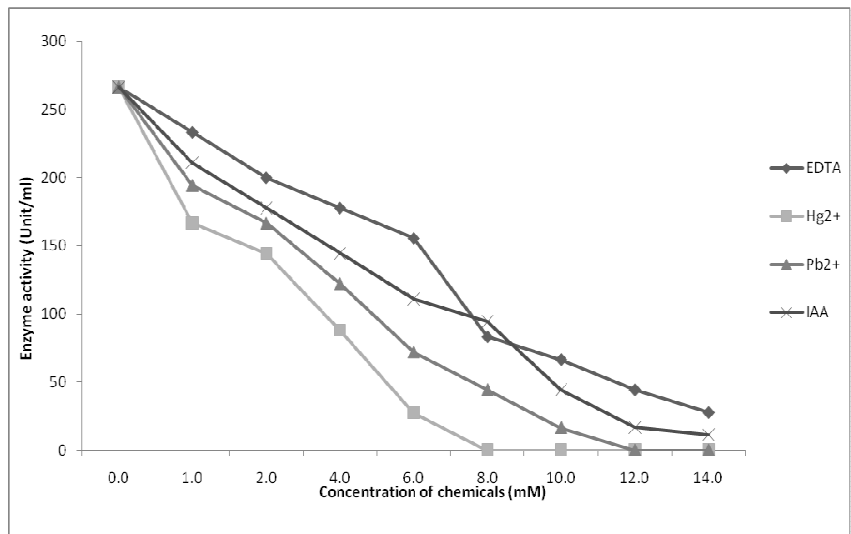

Figure 7: Effect of chemicals (Inhibitors) on purified (SP C-50 fraction polygalacturonase activity of $A$. niger

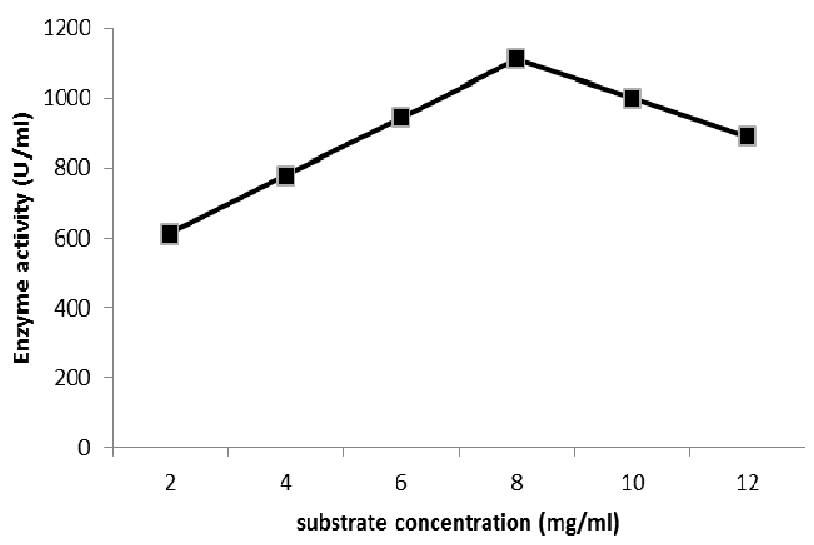

Figure 8: Effect of substrate concentration on purified (SP C-50 fraction) polygalacturonase activity of A.niger

(Oyede, 1990), Botryodiplodia theobromae Pat (Ajayi et al. 2003). A slightly higher temperature of $42{ }^{\circ} \mathrm{C}$ was reported for Rhizoctonia solani PG, while temperature optima of $45{ }^{\circ} \mathrm{C}$ to $50{ }^{\circ} \mathrm{C}$ were reported for $\mathrm{PG}$ from
Ventaria inequalis and A.alliaceus. The variations in the temperature optimum of $P G$ of these fungi suggest a broad range of temperature tolerable by the enzyme. In addition, the nature, sources and differences in the physiological activities of the fungi may be responsible for these observations (Arotupin, 1991).

\section{Temperature stability}

The fairly stable nature or the $P G$ from $A$. niger at $60{ }^{\circ} \mathrm{C}$ for 35 mins is of great significance in biotechnological processes (Favela Torres et al., 2006). Percentage loss of activity of $\mathrm{PG}$ obtained from $A$. niger, Botryodiplodia theobromae and Penicillium variabile heated at $70{ }^{\circ} \mathrm{C}$ have been reported (Oyede, 1998; Ajayi et al., 2003). Daniel et al. (1996) also reported thermal inactivation of enzymes at high temperature. In addition, extremely high temperature could lead to deamination, hydrolysis of the peptide bonds, interchange, and destruction of disulphide bonds and oxidation of the amino acids side chains of the enzyme protein molecules (Creighton, 1990; Daniel et al., 1996).

\section{pH optimum}

Maximum activity at $\mathrm{pH} 4.50$ was attained by $\mathrm{PG}$ of $A$. niger (Figure 4). The moderately acidic nature of the $A$. niger PGase in this study corroborated the influence of $\mathrm{pH}$ on PGases activity. At certain $\mathrm{pH}$, the activity of PGase was at maximum and changes in $\mathrm{pH}$ either to higher or lower values cause significant lowering of the enzyme activity. However, since catalytic power is often confined to a relatively small range of $\mathrm{pH}$, it is probable not unlikely that only one of the ionic forms or rather the active site of the enzyme is catalytically active (Dixon and Webbs, 1971). Dixon and Webbs (1971) and Conn and Stump (1989) separately reported that changes in $\mathrm{pH}$ have an effect on the affinity of the enzyme for the substrate.

\section{Effect of cations (salts)}

The maximum PG activity occurred at concentration 35 $\mathrm{mM}$ of $\mathrm{K}^{+}$and $\mathrm{Mg}^{2+}$ and at $30 \mathrm{mM}$ of $\mathrm{Na}^{+}$, while concentration of $15 \mathrm{mM} \mathrm{Ca}^{2+}$ and $\mathrm{Zn}^{2+}$ accounted for maximum $P G$ activity of $A$. niger (Figure 5 ). In this study, certain concentrations of cations were stimulatory, while others were inhibitory to the PG. The concentrations of $\mathrm{Ca}^{2+}$ and $\mathrm{Zn}^{2+}$ beyond $15 \mathrm{~mm}$ were inhibitory. Notably, concentrations of $\mathrm{K}^{+}, \mathrm{Na}^{+}$and $\mathrm{Mg}^{2+}$ were stimulatory to PG activity of $A$. niger. Oyede (1998) reported the stimulatory role of $\mathrm{K}^{+}, \mathrm{Na}^{+}$and $\mathrm{Mg}^{2+}$ on $\mathrm{PG}$ activity from Penicillium variabile, while concentrations of ca+ beyond $15 \mathrm{mM}$ inhibited the enzyme activity. Also Ajayi et al. (2003) reported the stimulatory action of the increased concentrations of $\mathrm{Ca}^{2+}, \mathrm{Mg}^{2+}, \mathrm{Zn}^{2+}$ and $\mathrm{K}^{+}$on $\mathrm{PG}$ activity produced by Botryodiplodia theobromae Pat with $\mathrm{Zn}^{2+}$ concentration above $10 \mathrm{mM}$ being inhibitory. These degrees of stimulation and inhibition could be a function of the sources of enzyme from different mould genera. Also in a situation where concentrations employed stimulated enzyme activities, the highest concentrations are not 
Table 2: Effect of PG concentrations on pineapple juice characteristics

\begin{tabular}{|c|c|c|c|c|c|c|}
\hline \multirow[t]{2}{*}{ Juice characteristics } & \multirow[t]{2}{*}{ Time (mins) } & \multicolumn{5}{|c|}{ Concentration of PG (\%) } \\
\hline & & 0.2 & 0.4 & 0.6 & 0.8 & 1.0 \\
\hline \multirow[t]{6}{*}{$\operatorname{Brix}(T S S)$} & 0 & $4.90 a$ & $4.90 a$ & $4.90 a$ & $4.90 a$ & $4.90 \mathrm{a}$ \\
\hline & 10 & $4.90 a$ & $6.60 b$ & $7.00 \mathrm{~b}$ & $7.60 \mathrm{~b}$ & $9.60 b$ \\
\hline & 30 & $7.00 \mathrm{~b}$ & $7.90 c$ & $8.60 c$ & $10.00 c$ & $11.00 \mathrm{c}$ \\
\hline & 60 & $8.60 \mathrm{c}$ & $10.20 d$ & $10.60 d$ & $11.6 d$ & $12.80 d$ \\
\hline & 90 & $10.00 d$ & $10.50 d$ & 11.70de & $12.90 \mathrm{e}$ & $13.30 d$ \\
\hline & 120 & $10.60 d$ & $11.90 \mathrm{e}$ & $12.20 \mathrm{e}$ & $13.20 \mathrm{e}$ & $13.50 d$ \\
\hline \multirow[t]{6}{*}{$\%$ Acidity } & 0 & $0.24 a$ & $0.24 a$ & $0.24 a$ & $0.24 a$ & $0.24 \mathrm{a}$ \\
\hline & 10 & $0.24 a$ & $0.38 b$ & $0.56 b$ & $0.62 b$ & $0.63 b$ \\
\hline & 30 & $0.44 b$ & $0.59 c$ & $0.69 c$ & $0.74 b c$ & $0.76 c$ \\
\hline & 60 & $0.58 c$ & $0.66 \mathrm{~cd}$ & $0.78 \mathrm{~cd}$ & $0.80 \mathrm{~cd}$ & $0.76 c$ \\
\hline & 90 & $0.66 \mathrm{~cd}$ & $0.78 \mathrm{de}$ & $0.83 d$ & $0.89 d$ & $0.88 c$ \\
\hline & 120 & $0.72 \mathrm{~d}$ & $0.83 e$ & $0.86 \mathrm{~d}$ & $0.92 d$ & $0.88 \mathrm{c}$ \\
\hline \multirow[t]{6}{*}{$\mathrm{pH}$} & 0 & $3.07 a$ & $3.07 a$ & $3.07 a$ & $3.07 a$ & $3.07 a$ \\
\hline & 10 & $3.11 \mathrm{ab}$ & $3.49 b$ & $3.69 b$ & $3.71 b$ & $3.72 b$ \\
\hline & 30 & $3.52 b$ & $4.27 c$ & $4.67 c$ & $4.87 c$ & $5.12 c$ \\
\hline & 60 & $4.07 c$ & $4.97 d$ & $5.07 c$ & $5.32 d$ & $5.49 c$ \\
\hline & 90 & $4.67 d$ & $5.32 \mathrm{de}$ & $5.67 d$ & $5.87 e$ & $5.97 d$ \\
\hline & 120 & $5.47 e$ & $5.69 e$ & $5.97 d$ & $6.07 e$ & $6.08 d$ \\
\hline \multirow[t]{6}{*}{ Juice yield } & 0 & $67.67 a$ & $67.67 a$ & $67.67 a$ & $67.67 a$ & $67.67 a$ \\
\hline & 10 & $67.67 a$ & $69.67 a$ & $79.67 b$ & $81.67 b$ & $81.67 b$ \\
\hline & 30 & $75.67 b$ & $77.67 b$ & $87.67 \mathrm{c}$ & $89.67 c$ & $87.67 \mathrm{bc}$ \\
\hline & 60 & $77.67 \mathrm{~b}$ & $79.67 b$ & $93.67 \mathrm{~cd}$ & $93.67 \mathrm{c}$ & $87.67 \mathrm{bc}$ \\
\hline & 90 & $77.67 \mathrm{~b}$ & $79.67 b$ & $95.67 d$ & $95.67 \mathrm{c}$ & $89.67 c$ \\
\hline & 120 & $79.67 b$ & $79.67 b$ & $95.67 d$ & $95.67 \mathrm{c}$ & $89.67 c$ \\
\hline \multirow[t]{6}{*}{ Pectin content } & 0 & $0.28 b$ & $0.28 d$ & $0.28 d$ & $0.28 d$ & $0.28 c$ \\
\hline & 10 & $0.31 b$ & $0.22 c$ & $0.17 c$ & $0.15 c$ & $0.13 b$ \\
\hline & 30 & $0.29 b$ & $0.19 b c$ & $0.12 b$ & $0.10 b$ & $0.09 a$ \\
\hline & 60 & $0.23 a$ & $0.15 a b$ & $0.09 b$ & $0.06 a b$ & $0.04 a$ \\
\hline & 90 & $0.21 a$ & $0.11 a$ & $0.03 a$ & $0.02 a$ & $0.03 a$ \\
\hline & 120 & $0.19 a$ & $0.11 a$ & $0.03 a$ & $0.02 a$ & $0.03 a$ \\
\hline
\end{tabular}

*Numbers with the same letter among the juice characteristics of each concentration of PG were not significantly different at $p<0.05$ and $n=3$.

necessarily the best for maximum activation as earlier reported to cause reduction in enzyme activation and even lead to enzyme inhibition ( $\mathrm{Ng}$ and Peikus, 1981; Dudchenko, 1986). Murray et al. (1990) showed the formation of a chelate compound between the substrate and metal ions could form a more stable metal-enzymesubstrate complex and stabilizing the catalytically active protein conformation. Added to this could be that metal ions which could not activate directly could act indirectly by ensuring that the true activating metal ions combine only with the active centre. Brown and Kelly (1993) affirmed the ability of metal ions often acting as salt or ion bridges between two adjacent amino acids.

All the concentrations of EDTA, $\mathrm{Hg}^{2+}, \mathrm{Pb}^{2+}$ and IAA were inhibitory to the activity of polygalacturonase and even lead to complete loss of activity (Figure 6). This study is inconsonance with the reports of Whitaker (1972), 
Torchinsky (1981) and Ajayi et al. (2003) who reported that $\mathrm{Hg}^{2+}$ and $\mathrm{Pb}^{2+}$ reacted with protein sulphydryl group converting it to marcaptides as well as imidazole, carboxyl and peptide group. The resultant effects of which lead to the denaturation of disulphide by catalytic acid of $\mathrm{Hg}^{2+}$ and $\mathrm{Pb}^{2+}$. Famurewa et al. (1993) and Sakamoto et al. (1994) attested the inhibitory activity of ETDA on enzyme. The metal building reagent like EDTA can inactivate enzyme either by removing the metal ions from the enzyme forming coordination complex, or by building inside enzyme as a ligand (Schmid, 1979). The changes in the reaction mixture occasioned by the IAA toward acidity could probably be responsible for the $P G$ inhibition. Arotupin (1991) observed that changes in $\mathrm{pH}$ either to higher or lower values significantly inhibited enzyme activity.

\section{Enzyme kinetics}

The PG of A.niger attained maximum at $8 \mathrm{mg} / \mathrm{mL}$ and further increase in substrate concentration resulted in decline of the enzyme activity (Figure 7). The PG had an apparent $\mathrm{Km}$ value of approximately $2.7 \mathrm{mg} / \mathrm{mL}$. The initial increase in the PG activity with increased substrate concentration until optimum was reached may be as a result of the effective binding of the substrate to the active site (Arotupin et al., 2008). This could be explained in term of the enzyme-substrate affinity cum the rate of the breakdown of the enzyme-substrate complex to form the products. The observed decline in the PG activity after the optimum could be due to the enzyme saturation and that, further increase in substrate concentrations resulted in over saturation of the enzyme without binding. In this situation, the substrate molecules crowd enzyme leading to the formation of ineffective enzyme-substrate complexes. A monomolecular competitive inhibition may occur leading to decline in activity. The apparent $\mathrm{Km}$ value of approximately $2.7 \mathrm{mg} / \mathrm{mL}$ indicated that the half active sites of the PG from $A$. niger could easily be filled. Therefore, this low $\mathrm{Km}$ value signified strong affinity of this enzyme for the substrate.

\section{Clarification potentials of the purified enzyme}

The effects of purified PG on the characteristics of pineapple juice are illustrated in Table 2. The highest yield of juice was observed at PG of 0.6 to $0.8 \% \mathrm{v} / \mathrm{w}$ equivalents to $200 \mathrm{U} / \mathrm{mL}$ and $220 \mathrm{U} / \mathrm{mL}$ with total solid content of 12.20 and 13.20 . The hydrolysis time was 90 mins and 120 mins with $\mathrm{pH} 6.10$ and 6.20 respectively. However, the PG activity increased with time and concentration. The increase in the juice flow as a result of the treatment with the purified $P G$ attested to the breakdown of tissues holding the juice. Enzymic activity strongly affected the polyphenols in the fruit, resulting in the discolouration of the fruit, but the flavour tends to improve with enzyme processing (Akinola and Onaolapo, 2003).

In conclusion, the Aspergillus niger CSTRF produced copious polygalacturonase whose characteristics could be employed in fruits and juice industries. Also, the juice clarification could be attained with the appropriate enzyme dosage.

\section{REFERENCES}

Ajayi, A. A.; Olutiola, P. O. and Fakunle, J. B. (2003). Studies on Polygalacturonase associated with the deterioration of tomato fruits (Lycopersicon esculentum Mill) infected by Botryodiplodia theobromae Pat. Science Focus 5: 68 - 77.

Akinola, S. O. and Onadapo, T. O. (2003). Development studies on enzymic processing of Mango (Magnifera indica I.) Juice and senstory evaluation. Nigerian Journal of Microbiology 17 (2): 196 -198.

Akinyosoye, F. A. and Akinyanju, J. A. (1989). Effect of different carbon sources on the growth and sporulation of Geotrichum candidum. Nigerian Journal of Botany $2: 85$ - 95.

Akinyosoye, F. A. and Oboh, G. (2004). Effect of different carbon sources on growth and polygalacturonase activity of Phoma sorghina. Nigeria Journal of Biochemistry and Molecular Biology 19(2):77 - 81.

Alkorta.I; Garbisu, C.; Llama, M. J. and Serra, J. L. (1998). Industrial applications at pectic enzymes: A review. Process Biochemistry 33: 21 - 28.

Alves, M. H.; Trufem, S. F. B. and Milanez, A. I. (2002). Taxons de Mucor Fresen. (Zygomycota) em fezes de herbivoros, Recife, PE, Brasil. Review Brasilian Botany 25(2): 147-160.

AOAC (1984). Offical Methods of Analysis, $14^{\text {th }} \mathrm{ed}$. Association of Official Analytical Chemists, Washinton DC.

Arotupin, D. J. (1991). Studies on the microorganisms associated with the degradation of sawdust. M. Sc. Thesis, University of llorin, Ilorin, Nigeria.

Arotupin, D. J. (2007). Effect of different carbon sources on the growth and polygalacturonase activity of Aspergillus flavus isolated from cropped soils. Research Journal of Microbiology 2(4): 362-368.

Arotupin, D. J.; Akinyosoye, F. A. and Onifade, A. K. (2008). Purification and characterization of pectinmethylesterase from Aspergillus repens isolated from cultivated soil. African Journal of Biotechnology 7(12):1991-1998.

Barthe, J. P.; Canhenys, D. and Tauze, A. (1981). Purification and characterization of two polygalacturonase secreted by Collectotrichum lindemuthianum. Phytopathologusche Zeitschrift 106: $162-171$.

Bateman, D. F. and Millar, R. L. (1966). Pectin enzymes in tissue degradation. Annal Review Phytopathology 4: $119-146$.

Brown, S. H. and Kelly, R. M. (1993). Characterization of amylolytic enzymes, having both $\alpha-1,4$ and $\alpha-1,6$ hydrolytic activity from the thermppholic archaea, Pyrococcus furiosus and Thermococcus litoralis. Applied and Environmental Microbiology 59: 2612 - 
2621.

Caprari and C.; Bergmann, C.; Migheli, Q.; Salvi G.;Alberbersheim, P. Darvill, A.; Cervone, F. and De Lorenzo, G. (1993). Fusarium moniliforme secrectes four endopolygalacturonases derived from a single gene product. Physiological and Molecular Plant Pathology 43 : 453 - 462.

Casida, L. E. Jr. (1997). Industrial Microbiology. Enzymes as Fermentation Products $4^{\text {th }}$ edition, Wiley Eastern Limited New Delhi pp.390 - 401.

Chuku, E. C.; Onuegbu, B. A. and Osakwe, J. A. (2005). Activities of polygalacturonase and cellulose enzymes on Viscosity of the seed of Irvingia gabonesis (Bush Mango). Niger Delta Biologia 5(1): 76-78.

Conn, E. E. and Stump K. P. (1989). Outline of Biochemistry, $4^{\text {th }}$ edition. Wiley Eastern Limited, New Delhi, India pp. 629

Creighton, T. E. (1990). Protein Function: A practical Approach. Oxford University Press, Oxford 306pp.

Crotti, L. B.; Jabopr, V. A.; Chellegatti, M. A.; fonseca, M. J. and Said, S. (1999). Studies of pectic enzymes produced by Talaromyces flavus in submerged and solid substrate cultures. Journal of Basic Microbiology, 39: 49-260.

Daniel, R. M.; Dines, M. and Petach, H. H. (1996). The denaturation and degradation of stable enzymes at high temperatures. Biochemical Journal 317: 1 -11.

Debing, J.; Peijun, L.; Stagnitti, F. Xianzhe, X. and Li, L. (2006). Pectinase production by soild fermentation from Aspergillus niger by a new prescription experiment. Ecotoxicology and Environmental Safety 64:244-250.

Dixon, M. and Webbs, E. C. (1971). Enzymes Williams Clowes and Sons. Great Britain 950 337pp.

Dudchenko, L. G. (1986). Effect of metal ions on the activity of pectolytic enzymes of the higher basidia fungus Coriolus hirsutuo. Geol Khim Biol Nauk 10:59 -62 .

Famurewa. O. Oyede. M. A. and Olutiola P. O. (1993). Pectin transeliminase complex in culture filterates of Aspergillus flavus. Folia Microbiol. 38: 459 - 466.

Favela-Torres, E.; Volke-Sepulveda, T. and ViniegraGonzalez, G. (2006). Production of hydrolytic depolymerising pectinases. Food Technology and Biotechnology 44(2):221-227.

Fontana, R.C.; Salvador, S. and Da Silveira M.M. (2005). Influence of pectin and glucose on growth and polygalacturonase production by Aspergillus niger in solid-state cultivation. Journal of India Microbiology and Biotechnology 32:371-377.

Forgarty, W. M. and Kelly, C. T. (1983). Pectic enzymes. In Microbial Enzymes and Biotechnology. FORGARTY, W. M. (ed.) Applied Science Publishers. London pp.131 - 182.

Friedrich, J.; Cinerman, A. and Steiner, W. (1990). Production of pectolytotic enzymes by Aspergillus niger. Effect of inoculum size and Potassium Hexacyanoferrate II Trihydrate. Applied Microbiology and Biotechnology 33: 377.
Geo, S. and Shain, L. (1994). Characterization of an enopolygalacturonase produced by chestnut blight fungus. Physiological and Molecular Plant Pathology $45: 169$ - 179.

Hugouvieux, K.; Centis, S.; Latitte, C. and EsquerreTugaye, M. T. (1995). Characterization of Collectotrichum lindermuthianum endopolygalacturonase with molecular probes. Camptes Rendus del' Academie des Scienecs, series III Science de la vre $318: 113-120$.

Jarvis, M. C.; Therelfall, D. R. and Friend, J. (1982). Potato (Solani tuberousin cultivar King Edward) cell wall polysaccharide degradation. Journal of Experimental Botany. 32 : 1309-1321.

Jayani, R.S.; Saxena, S. and Gupta, R. (2005). Microbial pectinolytic enzymes: A review. Process Biochemistry 40:2931-2944.

Kimural, H.; Uchino, O. and Mizushima, S. (1993). Properties of a Polygalacturonase produced by Acrocylinderium. Journal of General Microbiology 74: $127-137$.

Kluskens, I.D.; Van Alebeek, G.J.W.; Wayther, J.; Vorragen, A.G.J.; De Vos, W.M. and Van Deroost, J. (2005). Characterization and mode of action of an exopolygalacturonase from the hyperthermophilic bacterium Thermotoga maritima. FEBS Journal 272:5464-5473.

Lowry, O. H.; Rosebrough, N. J.; Farr, A. L. and Randall, R. J. (1951). Protein measurement with Folin-phenol reagent. Journal of Biological Chemistry $193: 265-275$.

Miller, G. L. (1959). Use of dinitrosalicylic acid reagent for determination of reducing sugar. Analytical Chemistry $31: 426-432$.

Mills, P. R. and Wood, R. K. S. (1985). Degradation of cell wall material from unprotected and systematically protected cucumber plants by extracellular enzymes of Collectotrichum lagenarium. Transaction of Bristish Mycological Society 85 : 291 - 298.

Murray, R. K.; Granner, D. K. and Mayes, P. A. (1990). Harpers Biochemistry. Appleton and Lange, Connecticut, USA 720 pp.

Ng, T. K. and Peikus, J. G. (1981). Comparison of extracellulase activities of Clostridium thermocellium LQR1 and Trichoderma reesei Q MR9414. Applied and Environmental Microbiology 42: 231 - 248.

Niture, S.K. and Pant, A. (2004). Purification and biochemical characterization of polygalacturonase 11 produced in semi-solid medium by a strain of Fusarium moniliforme. Microbiological Reseaarch 159:305-314.

Odutola, O. O. and Ikenebomeh, M. J. (1997). Polygalacturonase and pectinmethylestherase produced by Erwinia carotovora and Fusarium oxysporum isolated from stared tomatoes (Lycopersicum esulentum) fruits. Nigerian Journal of Microbiology 11: 108 - 111.

Olutiola, P. O. (1982a). Extracellular polygalacturonase enzyme complex from Penicellium citrinum. Thom associated with internal mouldness of cocoa 
Theobroa cacae) beans. Aceta Phytopathological Cademiae Saentiarum Hungaricae 17: 239 - 247.

Olutiola, P. O. (1982b). Polygalacturonase and pectinlyase of Penicillium sclerotigenum. Nigerian Journal of Microbiology 2: 154 - 167.

Olutiola, P. O. and Akintunde, O. A. (1979). Pectinlyases and pectinmethylesterase production by Pennicillium citrinum. Transaction of British Mycological Society $72: 49-55$.

Olutiola, P. O. and Ayres, P. G. (1973). Utilization of carbohydrates by Rhynchosporium secalis I. Growth and sporulation on glucose, galactose and galacturonic acid. Physiologia Plantarium 29 : 92 96.

Oyede, M. A. (1998). Studies on cell wall degrading enzymes associated with degradation of cassava (Manihot esculenta) tubers by some phytopathogenic fungi. Ph. D Thesis, Obafemi Awolowo University, Nigeria.

Palaniyappan, M.; Vijayagopai, V.; Viswannathan, R. and Viruthagiri, T. (2009). Screening of natural substrates and optimization of operating variables on the production of pectinase by submerged fermentation using Aspergillus niger MTCC 281. African Journal of Biotechnology 8(4): 682-686.

Parvateesan, M. and Verma, S. (1992). Enzyme production in Pseudomonas isolated from rotten vegetables. Indian Journal of Mycology and Plant Pathology 22 (1) 197 - 198.

Perez-Artes, E. and Tena, M. (1989). Pectic enzymes from two races of Fusarium oxysporum $\mathrm{f} s p$. cicerri. Enzymes production in culture and enzymatic activity on isolated chickpea cell wall. Journal of Phytopathology $124: 39-51$.

Peter, J. C.; Thomas, E. C.; Robert, L. B. and Jav, E. M. (1990). Variation in polygalacturonase production among Aspergillus flavus isolates. Applied and Environmental Microbiology 56 (12) : 3885 - 3887.

Phaff, H. J. (1996). I, 4 - polygalacturonase gylcanohydrase (endo-polygalacturonase) from Saccharomyces fragilis. Methods in Enzymology 8 : $636-641$.

Rose, A. H. (1980). Economic Microbiology : Microbial Enzymes and Bioconversion. Academic Press Inc. London $5: 2270282$.

Sakamoto, T.; Hours, R. A. and Sakai, T. (1994). Purification, characterization and production of two pectic transeliminases with protopectinase activity from Bacillus subtilis, Bioscience, Biotechnology and Biochemistry $58: 353-358$.

Schmid, R. D. (1979). Protein Function: A practical Approach. Ed. T. E. Creighton. Oxford University Press, Oxford, New York. 306 pp.

Sharma, R. L. and Kaul, J. L. (1989). Studies of pectic enzymes in the rotting of apple by Monilinia spp. Indian Journal of Mycology and Pathology 19 (1) : 30 $-37$.

Silva, D.; Da Silva-Martins, E.; Da Silva, R. and Gmes, E. (2002). Pectinase Production by Penicillium viridicatum RFC3 by solid states fermentation using agricultural wastes and agro-industrial by products. Brazilian Journal of Microbiology 33 (4) : 1 - 10.

Soares, M. M. C. N.; Da Silva, R. and Gomes, E. (1999). Screening of bacterial strains for pectinolytic activity characterization of the Pgase produced by Bacillus species. Review Microbiology 30: 229-303.

Solis, S.; Flores, M. E. and Huiton, C. (1996). Protoplasts from pectinolytic fungi : isolation, regeneration and pectionolytic enzyme production. Letters in Applied Microbiology 23 : 36 - 42.

Torchinsky, Y. M. (1981). Protein Function: A Practical Approach. Ed. T. E. Creighton. Oxford University Press, Oxford, New York, 306 pp.

Walton, J. D. and Cervone, F. (1990). Endopolygalacturonase from the maize pathogen Cochliobolus carbonum. Physiologica; and Molecular Plant Pathology 36: 351 - 359.

Weeransinghe, B. and Baqvi, S. H. Z. (1985). Some comparative physiological studies on selected isolates of Botryodiplodia theobromae pat. Causing storage of yam, Cassava and Sweet potato in Nigeria. International Biodeterioration $21: 225-228$.

Whitaker, D. R.; Hanson, K. R. and Datta, P. K. (1963). Improved procedure for preparation and characterization of Myrotheecium cellulase. Part 2: Purification Procedures. Canadian Journal of Biochemistry and Physiology 41: 671 - 696.

Whitaker, J. R. (1972). Principles of Enzymology for the Food Science. Marcel Dekker, Inc. New York 636 pp.

Yoon, S.; Kim, M. K.; Hong, J., S. and Kim, M. S. (1994). Purification and properties of polygalacturonase from Genoderma incidum. Korean Journal of Mycology 22: 298 - 304. 